
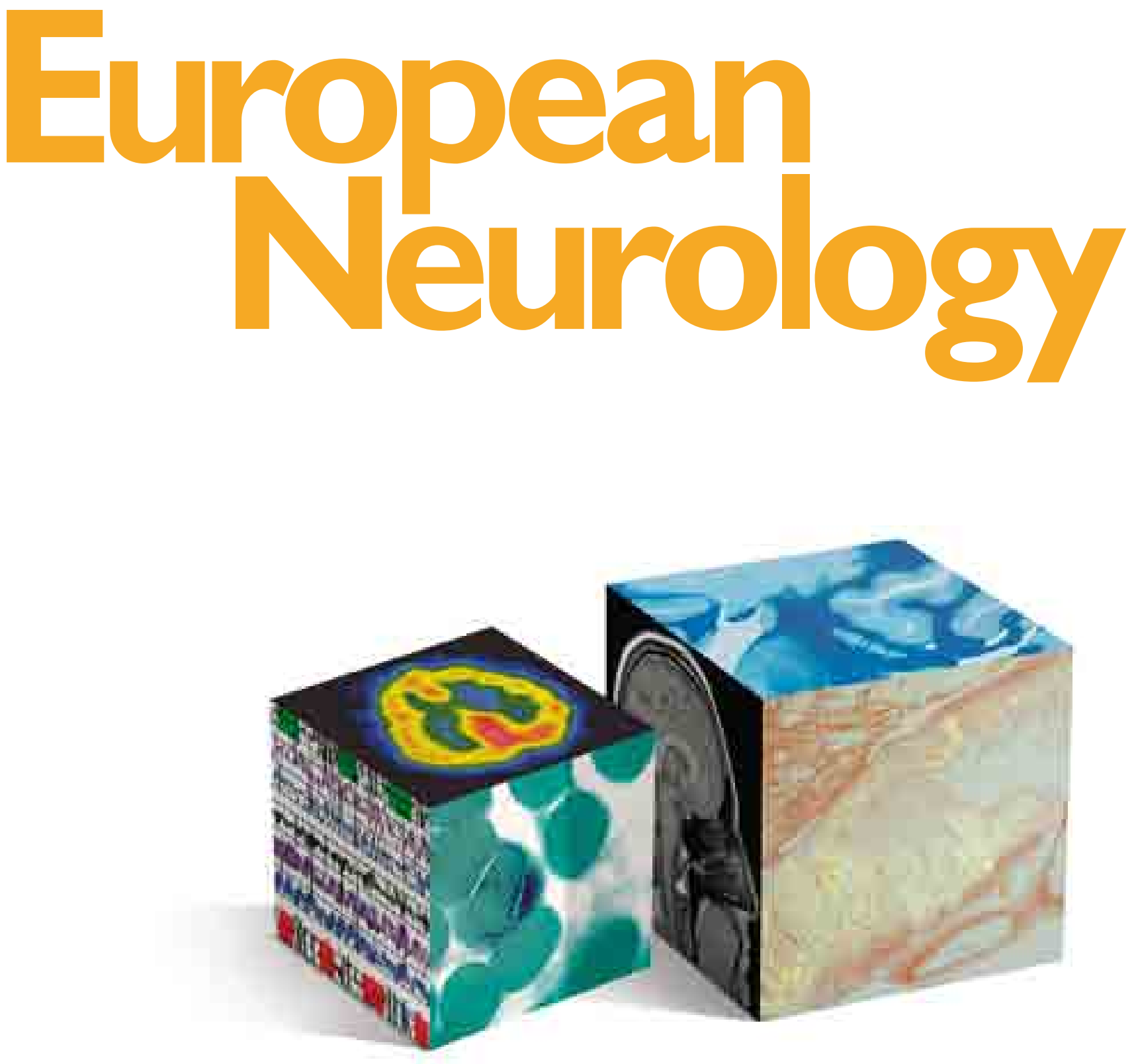


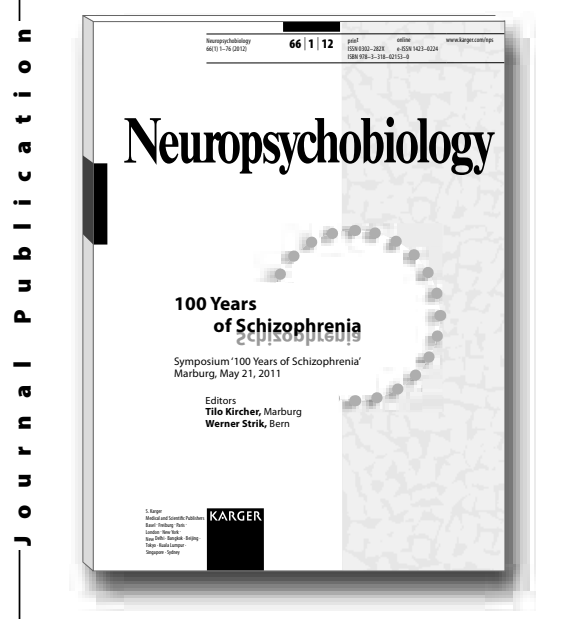

The articles in this issue are based on a symposium that was held in Marburg to celebrate the 100th anniversary of the publication of Eugen Bleuler's monograph on schizophrenia. They discuss all aspects of schizophrenia in the light of data from current research and review current hypotheses of neurobiological correlates of delusions, hallucinations and ego disturbances. In addition, topics such as reelin expression in the cortex, neural activation during reward processing in subjects with an ultrahigh risk for schizophrenia, brain structural variations in patients and imaging endophenotypes are discussed. Included are also a number of comprehensive reviews on earlyonset schizophrenia and psychosocial interventions. It concludes with a presentation of Eugen Bleuler's concept of schizophrenia and its relevance to present-day psychiatry.

This issue will provide valuable reading for all researchers and clinicians in fields such as psychiatry and psychology as well as for psychotherapists and neurologists.

\section{Years of Schizophrenia}

\author{
Editors \\ Tilo Kircher \\ Werner Strik
}

\section{Contents}

Preface

Eugen Bleuler's Concept of Schizophrenia and Its Relevance to Present-Day Psychiatry: Hoff, $\boldsymbol{P}$.

Semantic Network Disconnection in Formal Thought Disorder: Horn, $\boldsymbol{H}$.; Jann, $\boldsymbol{K}_{\text {;; }}$ Federspiel, A.; Walther, S.; Wiest, R.; Müller, T.; Strik, $\boldsymbol{W}$.

A Possible Brain Network for Representation of Cooperative Behavior and Its Implications for the Psychopathology of Schizophrenia: Leube, D.; Straube, B.;

Green, A.; Blümel, I.; Prinz, S.; Schlotterbeck, P.; Kircher, $T$.

Neurobiological Correlates of Delusion: Beyond the Salience Attribution Hypothesis: Pankow, A.; Knobel, A.; Voss, M.; Heinz, A.

Heterogeneity of Brain Structural Variation and the Structural Imaging Endophenotypes in Schizophrenia: Nenadic, I.; Gaser, C.; Sauer, $H$.
Ventral Striatal Activation during Reward Processing in Subjects with Ultra-High Risk for Schizophrenia: Juckel, G.; Friedel, E.; Koslowski, M.; Witthaus, H.; Özgürdal, S.; Gudlowski, Y.; Knutson, B.; Wrase, J.; Brüne, M.; Heinz, A.; Schlagenhauf, $F$.

Decreased Reelin Expression in the Left Prefrontal Cortex (BA9) in Chronic Schizophrenia Patients: Habl, G.; Schmitt, A.; Zink, M.; von Wilmsdorff, M.; Yeganeh-Doost, P.; Jatzko, A.;

Schneider-Axmann, T.; Bauer, M.; Falkai, $P$.

Early-Onset Schizophrenia: Remschmidt, $\boldsymbol{H}_{\text {.; }}$ Theisen, $F$.

Psychosocial Interventions in People with Severe Mental Illness: A Bleulerian Perspective: Becker, T.; Kösters, $\boldsymbol{M}$.

Author Index/Subject Index
100 Years of Schizophrenia

Editors: Kircher, T. (Marburg); Strik, W. (Bern)

76 p., 12 fig., 5 in color, 21 tab., hard cover, 2012

CHF 29.- / EUR 24.- / USD 34.00

Prices subject to change

EUR price for Germany, USD price for USA only

ISBN 978-3-318-02153-0

e-ISBN 978-3-318-02154-7

\section{Special Topic Issue}

Neuropsychobiology

Vol. 66, No. 1 (2012)

Included in subscription
Please send: _ copy/ies

Postage and handling free with prepayment

E

Payment:

Please charge to my credit card

- $\square$ American Express $\square$ Diners

ᄂ $\square$ MasterCard $\square$ Visa

- Card No.

o

ర Exp. date:

- $\mathrm{CVV} / \mathrm{CV}$

( 3 digits in the signature field on the back of Visa and MasterCard)

$\square$ Check enclosed $\square$ Please bill me

Orders may be placed with any bookshop, subscription agency, directly with the publisher or through a Karger distributor.
Fax: +41 613061234

S. Karger AG, P.O. Box, CH-4009 Basel (Switzerland)

E-Mail orders@karger.ch, www.karger.com

Name/Address: 


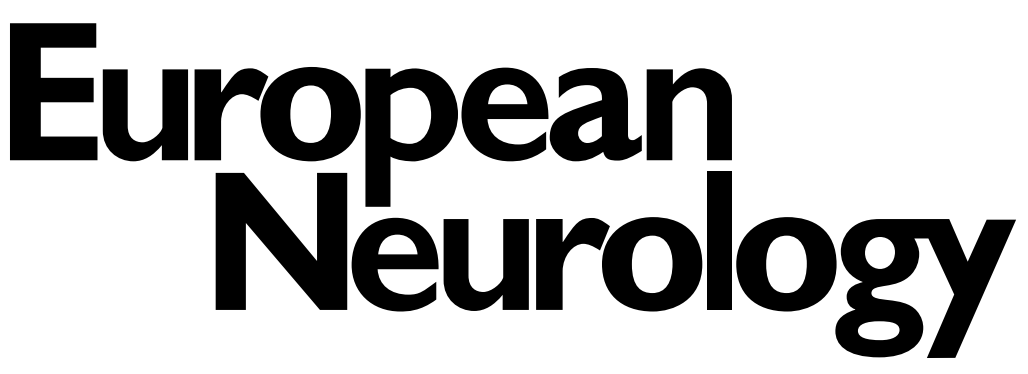

Founded 1897 as 'Monatsschrift für Psychiatrie und Neurologie', continued 1957-1967 as 'Psychiatria et Neurologia'

Founders: C. Wernicke and Th. Ziehen.

Successors: K. Bonhoeffer (1912-1938), J. Klaesi (1939-1967), E. Grünthal (1953-1967),

H.E. Kaeser (1968-1993)

\section{Editor-in-Chief}

J. Bogousslavsky, Montreux

\section{Editorial Board}

H. Adeli, Columbus, Ohio

A. Amato, Boston, Mass.

J.-M. Annoni, Fribourg

S.R. Benbadis, Tampa, Fla.

F. Boller, Rockville, Md.

E. Broussolle, Lyon

C. Buckley, Oxford

J.-M. Burgunder, Berne

R.J. Castellani, Baltimore, Md.

A.K. Chatterjee, Philadelphia, Penn.

N.M.J. Edelstyn, Staffordshire

G.R. de Freitas, Rio de Janeiro

J.L. de Reuck, Gent

G. Deuschl, Kiel

V. Di Piero, Rome

T. Ettlin, Rheinfelden

M. Filippi, Milan

S. Gauthier, Montreal, Que.

P. Giannakopoulos, Geneva

F. Graus, Barcelona

B. Greenberg, Dallas, Tex.

H.-P. Hartung, Düsseldorf

R.A. Hauser, Tampa, Fla.

J.J. Hauw, Paris

T.S. Jensen, Aarhus

R.N. Kalaria, Newcastle upon Tyne

T. Karapanayiotides, Thessaloniki

J.S. Kim, Seoul

K. Kimura, Kurashiki
U. Koedel, Munich

H. Lassmann, Vienna

N. Leigh, London

K.O. Lövblad, Geneva

P. Maeder, Lausanne

A. May, Hamburg

M.N. Meriggioli, Chicago, Ill.

J. Mocayo Gaete, Quito

X. Montalban, Barcelona

T. Moulin, Besançon

H. Naritomi, Osaka

E. Nobile-Orazio, Milan

M. Paciaroni, Perugia

A.O. Rossetti, Lausanne

D. Russell, Oslo

S. Sacco, L'Aquila

K. Schaller, Geneva

M. Schüpbach, Berne

N. Scolding, Bristol

M. Seeck, Geneva

V. Silani, Milan

C.J.M. Sindic, Bruxelles

L. Tatu, Besançon

B.E. Tettenborn, St. Gallen

A. Tsiskaridze, Tbilisi

J.M. Vallat, Limoges

P. Van den Bergh, Brussels

B.V. Vaughn, Chapel Hill, N.C.

O.W. Walusinski, Brou
Printed in Switzerland on acid-free and non-aging paper (ISO 9706) by

Reinhardt Druck, Basel
Appears monthly: 2 volumes per year (12 issues) 


\section{European Neurology}

\section{Aims and Scope}

'European Neurology' publishes original papers, reviews and letters to the editor. Papers presented in this journal cover clinical aspects of diseases of the nervous system and muscles, as well as their neuropathological, biochemi$\mathrm{cal}$, and electrophysiological basis. New diagnostic probes, pharmacological and surgical treatments are evaluated from clinical evidence and basic investigative studies. The journal also features original works and reviews on the history of neurology.

Submission

Only original papers written in English are considered and should be submitted online:

\section{www.karger.com/ene}

Should you experience any problems with your submission, please contact:

\section{ene@karger.ch}

S. Karger AG

Editorial Office 'European Neurology'

P.O. Box

CH-4009 Basel (Switzerland)

Tel. +41613061573

Fax +4161306 1434

Names, postal and e-mail adresses of 6 experts in the appropriate area of research should accompany each manuscript. Referees suggested should not be from the same institution or be research collaborators of the author(s).

\section{Conditions}

All manuscripts are subject to editorial review. Manuscripts are received with the explicit understanding that they are not under simultaneous consideration by any other publication. Submission of an article for publication implies transfer of the copyright from the author to the publisher upon acceptance. Accepted papers become the permanent property of 'European Neurology' and may not be reproduced by any means, in whole or in part, without the written consent of the publisher. It is the author's responsibility to obtain permission to reproduce illustrations, tables, etc. from other publications.

\section{Conflicts of Interest}

Authors are required to disclose any sponsorship or funding arrangements relating to their research and all authors should disclose any possible conflicts of interest. Conflict of interest statements will be published at the end of the article.

\section{Ethics}

Published research must comply with the guidelines for human studies and animal welfare regulations. Authors should state that subjects have given their informed consent and that the study protocol has been approved by the institute's committee on human research. Further, they should also state that animal experiments conform to institutional standards.

\section{Categories of Manuscripts}

Original Papers are full-length research papers which will be considered for the journal. Articles cover topics relevant to clinical studies. Basic and experimental work appear only if directly related to clinical issues (max. 3000 words)

Reviews are comprehensive, state-of-the-art papers of important clinical problems. Reviews may be invited by the Editor or they may be unsolicited views (max. 5000 words)

Neuroimages are previously unpublished photomicrographs, patient photographs, neuroradiologic images, or other pictorial material (max. 100 words, two figures with legend, and up to two references)

\section{Plagiarism Policy}

Whether intentional or not, plagiarism is a serious viola tion. We define plagiarism as a case in which a paper re produces another work with at least $25 \%$ similarity and without citation.
If evidence of plagiarism is found before/after acceptance or after publication of the paper, the author will be offered a chance for rebuttal. If the arguments are not found to be satisfactory, the manuscript will be retracted and the author sanctioned from publishing papers for a period to be determined by the responsible Editor(s).

\section{Arrangement}

Title page: The first page of each paper should indicate the title, the authors' names, the institute where the work was conducted, and a short title for use as running head.

Full address: The exact postal address of the corresponding author complete with postal code must be given at the bottom of the title page. Please also supply phone and fax numbers, as well as e-mail address.

Key words: Please supply 3-10 key words in English that reflect the content of the paper.

Abstract: Each paper needs an abstract of up to 10 lines (except for letters to the editor).

Footnotes: Avoid footnotes.

Tables and illustrations: Tables and illustrations (both numbered in Arabic numerals) should be prepared on separate pages. Tables require a heading and figures a legend, also prepared on a separate page. For the reproduction of illustrations, only good drawings and original photographs can be accepted; negatives or photocopies cannot be used. Due to technical reasons, figures with a screen background should not be submitted. When possible, group several illustrations in one block for reproduction (max. size $180 \times 223 \mathrm{~mm}$ ) or provide crop marks. Electronically submitted b/w half-tone and color illustrations must have a final resolution of $300 \mathrm{dpi}$ after scaling, line drawings one of $800-1,200 \mathrm{dpi}$.

\section{Color illustrations}

Online edition: Color illustrations are reproduced free of charge. In the print version, the illustrations are reproduced in black and white. Please avoid referring to the colors in the text and figure legends.

Print edition: Up to 6 color illustrations per page can be integrated within the text at CHF 800.- per page.

References: In the text identify references by Arabic numerals [in square brackets]. Material submitted for publication but not yet accepted should be noted as 'unpublished data' and not be included in the reference list. The list of references should include only those publications which are cited in the text. Do not alphabetize; number references in the order in which they are first mentioned in the text. The surnames of the authors followed by initials should be given. There should be no punctuation other than a comma to separate the authors. Preferably, please cite all authors. Abbreviate journal names according to the Index Medicus system. Also see International Committee of Medical Journal Editors: Uniform requirements for manuscripts submitted to biomedical journals (www.icmje.org)

Examples

(a) Papers published in periodicals: Chatel J-M, Bernard $\mathrm{H}$, Orson FM: Isolation and characterization of two complete Ara h 2 isoforms cDNA. Int Arch Allergy Immunol 2003;131:14-18.

(b) Papers published only with DOI numbers:

Theoharides TC, Boucher W, Spear K: Serum interleukin-6 reflects disease severity and osteoporosis in mastocytosis patients. Int Arch Allergy Immunol DOI: $10.1159 / 000063858$.

(c) Monographs: Matthews DE, Farewell VT: Using and Understanding Medical Statistics, ed 3, revised. Basel, Karger, 1996.

(d) Edited books: DuBois RN: Cyclooxygenase-2 and colorectal cancer; in Dannenberg AJ, Dubois RN (eds) COX-2. Prog Exp Tum Res. Basel, Karger, 2003, vol 37, pp $124-137$
Reference Management Software: Use of EndNote is recommended for easy management and formatting of citation and reference lists.

\section{Digital Object Identifier (DOI)}

S. Karger Publishers supports DOIs as unique identifier for articles. A DOI number will be printed on the title page of each article. DOIs can be useful in the future for identifying and citing articles published online without volume or issue information. More information can be found at www.doi.org.

\section{Supplementary Material}

Supplementary material is restricted to additional data that are not necessary for the scientific integrity and conclusions of the paper. Please note that all supplementary files will undergo editorial review and should be submitted together with the original manuscript. The Editors reserve the right to limit the scope and length of the supplementary material. Supplementary material must meet production quality standards for Web publication without the need for any modification or editing. In general, supplementary files should not exceed $10 \mathrm{MB}$ in size. All figures and tables should have titles and legends and all files should be supplied separately and named clearly. Acceptable files and formats are: Word or PDF files, Excel spreadsheets (only if the data cannot be converted properly to a PDF file), and video files (.mov, .avi, .mpeg).

\section{Author's Choice ${ }^{\mathrm{TM}}$}

Karger's Author's Choice ${ }^{\mathrm{TM}}$ service broadens the reach of your article and gives all users worldwide free and full access for reading, downloading and printing at www. karger.com. The option is available for a one-time fee of CHF 3000.-, which is a permissible cost in grant allocation. More information can be found at www.karger.com/ authors_choice.

\section{NIH-Funded Research}

The U.S. National Institutes of Health (NIH) mandates under the NIH Public Access Policy that final, peer-reviewed manuscripts appear in its digital database within 12 months of the official publication date. As a service to authors, Karger submits the final version of your article on your behalf to PubMed Central. For those selecting our premium Author's Choice ${ }^{\mathrm{TM}}$ service, we will send your article immediately upon publishing, accelerating the accessibility of your work without the usual embargo. More details on NIH's Public Access Policy is available at http://publicaccess.nih.gov/policy.htm

\section{Self-Archiving}

Karger permits authors to archive their pre-prints (i.e. prerefereeing) or post-prints (i.e. final draft post-refereeing) on their personal or institution's servers, provided the following conditions are met: Articles may not be used for commercial purposes, must be linked to the publisher's version, and must acknowledge the publisher's copyright. Authors selecting Karger's Author's Choice ${ }^{\mathrm{TM}}$ feature, however, are also permitted to archive the final, published version of their article, which includes copyediting and design improvements as well as citation links.

\section{Page Charges}

There are no page charges for papers of 3 or fewer printed pages (including tables, illustrations and references). Each additional complete or partial page is charged to the author at CHF 325.-. The allotted size of a paper is equal to approx. 8 manuscript pages (including tables, illustrations and references).

\section{Proofs}

Unless indicated otherwise, proofs are sent to the corresponding author and should be returned with the least possible delay. Alterations other than the correction of printer's errors are charged to the author.

\section{Reprints}

Order forms and a price list are sent with the proofs. Orders submitted after the issue is printed are subject to considerably higher prices.

\section{KARGER}

Fax +41 613061234 E-Mail karger@karger.ch www.karger.com
(C) 2012 S. Karger AG, Basel 


\section{European Neurology} ISSN Online Edition: 1421-9913

Journal Homepage: www.karger.com/ene

Publication Data: 'European Neurology' is published 12 times a year. Volumes 67 and 68, each with 6 issues, appear in 2012

Copyright: (c) 2012 S. Karger AG, Basel (Switzerland). All rights reserved. No part of this publication may be translated into other languages, reproduced or utilized in any form or by any means, electronic or mechanical including photocopying, recording, microcopying, or by any information storage and retrieval system, without permission in writing from the publisher or, in the case of photocopying, direct payment of a specified fee to the Copyright Clearance Center.

Disclaimer: The statements, opinions and data contained in this publication are solely those of the individual authors and contributors and not of the publisher and the editor(s). The appearance of advertisements in the journal is not a warranty, endorsement, or approval of the products or services advertised or of their effectiveness, quality or safety. The publisher and the editor(s) disclaim responsibility for any injury to persons or property resulting from any ideas, methods, instructions or products referred to in the content or advertisements.
ISSN Print Edition: 0014-3022
Subscription Rates: Subscriptions run for a full calendar year. Prices are given per year. Personal subscription:

Print or Online

CHF 709.-

EUR 567--

USD 688.00

USD 782.00

postage and handling (added to print and print+online)

CHF 81.60 Europe, CHF 120.- Overseas

EUR 62.40

USD 112.80

Institutional subscription:

Print or Online

Print+Online combined

CHF 3544 .

CHF 3898.-

EUR 2836.-

EUR 3118.-

USD 3784.00

postage and handling (added to print and print+online)

CHF 102.- Europe, CHF 150.- Overseas

EUR 78.-

USD 141.00

Airmail surcharge: CHF 99.60 / USD 93.60

Discount subscription prices:

European Neurological Society;

Belgian Society of Neurology.
Print+Online combined
Back Volumes and Single Issues: Information on availability and prices of single print issues and print or electronic back volumes can be obtained from Customer Service at service@karger.ch.

Bibliographic Indices: This journal is regularly listed in bibliographic services, including Current Contents ${ }^{\circledR}$ and PubMed/MEDLINE.

Photocopying: This journal has been registered with the Copyright Clearance Center (CCC), as indicated by the code appearing on the first page of each article. For readers in the US, this code signals consent for copying of articles for personal or internal use, or for the personal or internal use of specific clients, provided that the stated fee is paid per copy directly to

Copyright Clearance Center Inc.

222 Rosewood Drive

Danvers, MA 01923 (USA)

A copy of the first page of the article must accompany payment. Consent does not extend to copying for general distribution, for promotion, for creating new works, or for resale. In these cases, specific written permission must be obtained from the copyright owner,

S. Karger AG, P.O. Box

CH-4009 Basel (Switzerland).
Subscription Orders:

Orders can be placed at agencies,

bookstores, directly with the Publisher

\section{S. Karger AG}

Medical and Scientific Publishers

P.O. Box

CH-4009 Basel

Switzerland

(for courier services only:

Allschwilerstrasse 10

CH-4055 Basel)

$\mathrm{t}:+41613061111$

f: +41613061234

e: karger@karger.ch w: www.karger.com or further Karger offices

or representatives:

Germany

S. Karger GmbH

Postfach

79095 Freiburg

Deutschland

(Hausadresse: Wilhelmstrasse 20A,

79098 Freiburg)

$\mathrm{t}: \quad+49761452070$

f: +497614520714

e: information@karger.de

w: www.karger.de

Japan

Karger Japan, Inc.

Shiba Daimon Asahi Bldg. 2F

1-2-23 Shiba Daimon

Minato-ku

Tokyo 105-0012

Japan

t: +81364356242

f: +81364356244

e: publisher@karger.jp

w: www.karger.jp
Change of Address:

Both old and new address should be sent to the subscription source.
USA

S. Karger Publishers, Inc.

26 West Avon Road

P.O. Box 529

Unionville, CT 06085

USA

Toll free: +1 8008285479

t: +18606757834

f: +18606757302

e: karger@snet.net

France

Librairie Médi-Sciences Sar

36, bd de Latour-Maubourg

75007 Paris

France

t: $+33(0) 145514258$

f: $+33(0) 145560780$

f: $+33(0) 145560780$

w: www.medi-sciences.fr

Gulf Council Countries, Iran,

Middle East, North Africa, Turkey

Trans Middle East International

Distribution Co. Ltd. (KaSha)

168 B, King Abdullah the 2nd Street

Daboog Building 2nd Floor

Daboog Area

P.O. Box 2376

Amman 11953

Jordan

t: +962 65153467

f: +96265411336

e: info@kasha.cc

w: www.KaShaonline.com
South East Asia, China and Taiwan Karger Regional Office (Malaysia)

CEO Suite Kuala Lumpur

Quill 7, 27th Floor

Jalan Stesen Sentral 5

KL Sentral

Kuala Lumpur 50470

Malaysia

t: +60327766803

f: +60327766999

e: service@karger.cn; r.chew@karger.cn

\section{Karger China}

10th Floor, Twin Towers (East)

B12 Jianguomenwai Avenue

Beijing 100022

China

t: +861051235033

f: +861051235122

e: service@karger.cn; r.chew@karger.cn

w: www.karger.cn

India, Bangladesh, Sri Lanka

Medscience India

Plot No. 17, Yusuf Sarai Market

B.L. Glass Building, 2nd Floor

Sri Aurobindo Marg

New Delhi 110016

India

t: +911146029633

f: +911146029634

c: +919891052128

e: medsci.india@gmail.com

\section{KARGER}

Fax +41 613061234

E-Mail karger@karger.ch

www.karger.com
(C) 2012 S. Karger AG, Basel

The Journal Home Page is available at:

www.karger.com/ene 


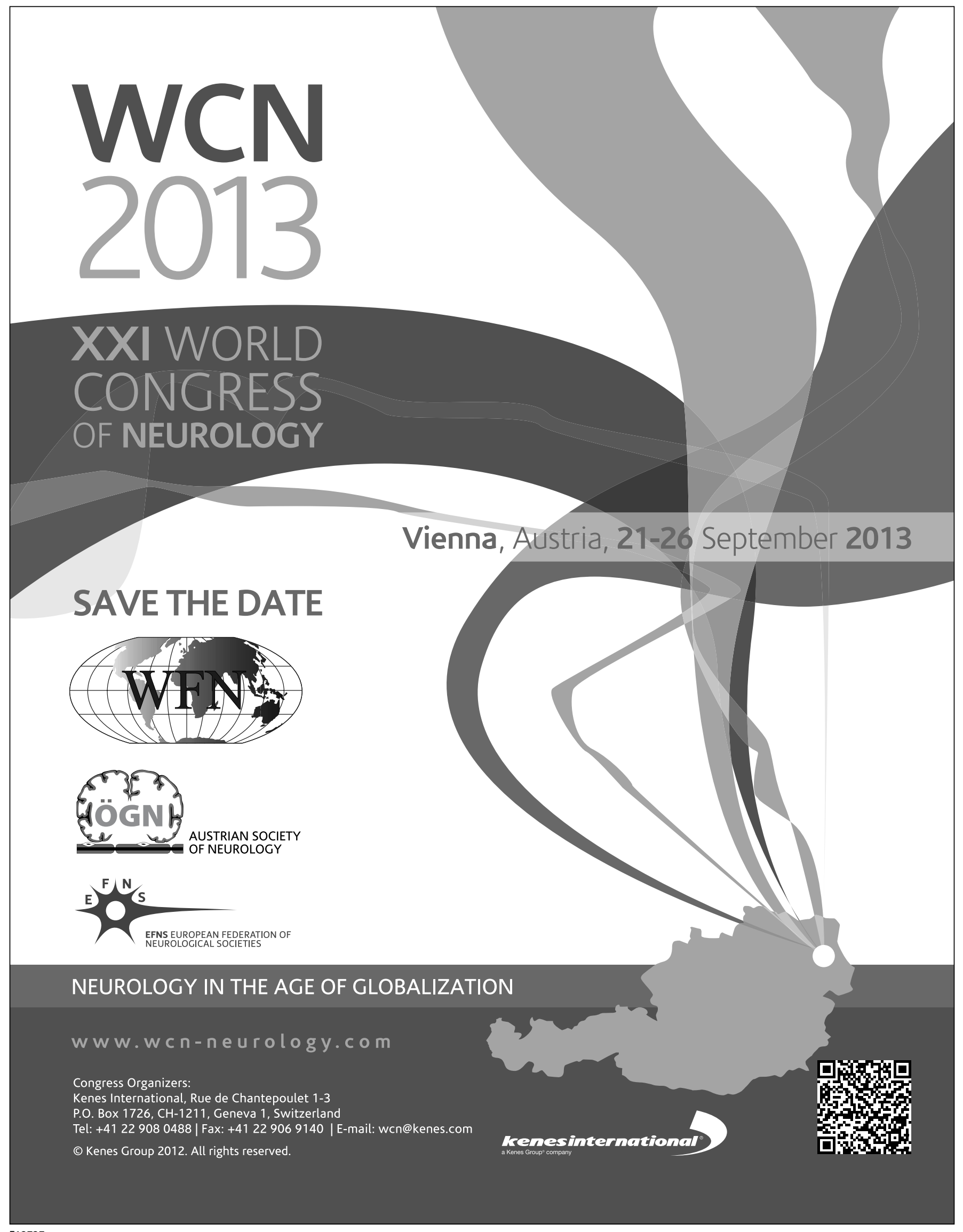




\section{Contents}

See the journal website for contents

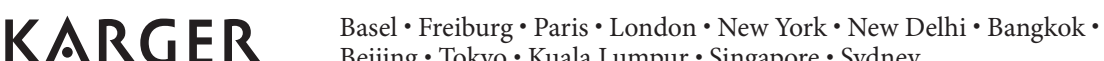
Beijing $\cdot$ Tokyo $\cdot$ Kuala Lumpur $\cdot$ Singapore $\cdot$ Sydney 


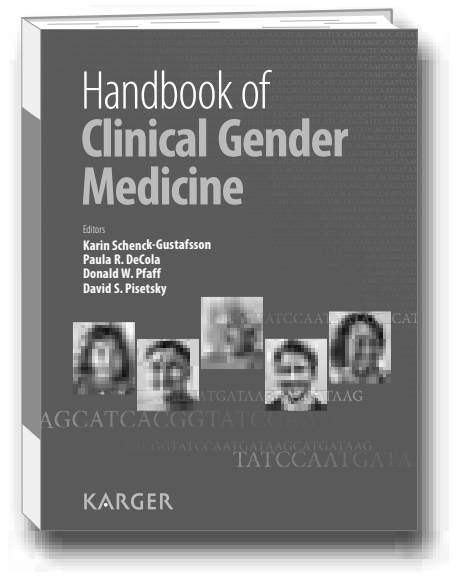

Gender medicine is an important new field in health and disease. It is derived from top-quality research and encompasses the biological and social determinants that underlie the susceptibility to disease and its consequences. In the future, consideration of the role of gender will undoubtedly become an integral feature of all research and clinical care.

Defining the role of gender in medicine requires a broad perspective on biology and diverse skills in biomedical and social sciences. When these scientific disciplines come together, a revolution in medical care is in the making. Covering twelve different areas of medicine, the practical and useful 'Handbook of Clinical Gender Medicine' provides up-to-date information on the role of gender in the clinical presentation, diagnosis, and management of a wide range of common diseases.

The contributing authors of this handbook are all experts who, in well-referenced chapters, cogently and concisely explain how incorporation of gender issues into research can affect the medical understanding and treatment of heart disease, osteoporosis, arthritis, pain, violence, and malaria among other conditions. This intriguing and unique medical textbook provides readers with a valuable new perspective to understand biology and incorporate gender issues into the different branches of medicine.

\section{Handbook of Clinical Gender Medicine}

\author{
Editors \\ Karin Schenck-Gustafsson \\ Paula R. DeCola \\ Donald W. Pfaff \\ David S. Pisetsky
}

\section{Contents}

Foreword: Wainer, J.; Wainer, $Z$.

Preface: Schenck-Gustafsson, $\boldsymbol{K}$.

\section{Introduction}

Gender Matters: Wainer, J.; Wainer, $\mathbf{Z}$.

Biological Sex and the Genome: What Makes

Us Ourselves? Legato, M.J.

\section{Social and Biological Determinants in \\ Health and Disease \\ Section Editors: DeCola, P.R.; Schober, J.M.}

\section{Central Nervous System and}

Clinical Applications

Section Editor: Pfaff, D.W.

\section{Neurology}

Section Editor: Olsson, $T$.

Pain

Section Editor: Murphy, A.Z.

Circulation

Section Editor: Schenck-Gustafsson, $\boldsymbol{K}$.

\section{Cancer}

Section Editor: Gustafsson, J.-Å.

\section{Metabolic Disease}

Section Editor: Werner, $\mathbf{s}$.

Autoimmune, Inflammatory, and

Musculoskeletal Disease

Section Editor: Pisetsky, D.S.

\section{Infectious Diseases}

Section Editor: Britton, $\mathbf{S}$.

\section{Urology, Sexual Dysfunction,} and Nephrology

Section Editor: Arver, $\mathbf{S}$.

\section{Pharmaceutical Drugs}

Section Editor: Parekh, A.

\section{Geriatrics}

Section Editor: Herlitz, $\boldsymbol{A}$.

Please see the full contents on: www.karger.com/gender_medicine

Handbook of Clinical Gender Medicine Editors: Schenck-Gustafsson, K. (Stockholm)

DeCola, P.R.; Pfaff, D.W. (New York, N.Y.); Pisetsky, D.S. (Durham, N.C.)

XVI + 522 p., 62 fig., 4 in color, 63 tab., soft cover, 2012 CHF 69.- / EUR 51.- / USD 69.00

Prices subject to change

EUR price for Germany, USD price for USA only

ISBN 978-3-8055-9929-0

e-ISBN 978-3-8055-9930-6
Please send: _ copy/ies

Postage and handling free with prepayment

E Payment:

Please charge to my credit card

- $\square$ American Express $\square$ Diners

ᄂ $\square$ MasterCard $\square$ Visa

- Card No

-

Exp. date:

- CVV/CVC

( 3 digits in the signature field on the back of Visa and MasterCard)

$\square$ Check enclosed $\square$ Please bill me

Orders may be placed with any bookshop, subscription agency, directly with the publisher or through a Karger distributor.
Fax: +41613061234

S. Karger AG, P.O. Box, CH-4009 Basel (Switzerland)

E-Mail orders@karger.ch,www.karger.com

Name/Address: 
Review

234 Motor Recovery Mechanisms in Patients with Middle Cerebral Artery Infarct: A Mini-Review

Jang, S.H. (Taegu)

Original Papers

193 PSMC1 Gene in Parkinson's Disease

Gómez-Garre, P.; Jesús, S.; Carrillo, F.; Cáceres-Redondo, M.T.; Bernal-Bernal, I.; Carballo, M.; Gao, L.; Mir, P. (Seville)

199 Effectiveness of Low-Frequency rTMS and Intensive Speech Therapy in Poststroke Patients with Aphasia: A Pilot Study Based on Evaluation by fMRI in Relation to Type of Aphasia

Abo, M.; Kakuda, W.; Watanabe, M.; Morooka, A.; Kawakami, K.; Senoo, A. (Tokyo)

209 Frequency and Mechanism of Ischemic Stroke Associated with Malignancy: A Retrospective Series Álvarez-Pérez, F.J. (Covilhã/Palma de Mallorca); Verde, I. (Covilhã); Usón-Martín, M.; Figuerola-Roig, A.;

Ballabriga-Planas, J.; Espino-Ibañez, A. (Palma de Mallorca)

214 Distal Hyperintense Vessels on Flair: A Prognostic Indicator of Acute Ischemic Stroke

Huang, X. (Nanjing/Wuhu); Liu, W.; Zhu, W. (Nanjing); Ni, G. (Wuhu); Sun, W. (Guangzhou); Ma, M. (Nanjing); Zhou, Z. (Wuhu); Wang, Q. (Shenzhen); Xu, G.; Liu, X. (Nanjing)

221 The Effect of Voluntary Training with Family Participation on Early Home Discharge in Patients with Severe Stroke at a Convalescent Rehabilitation Ward Hirano, Y. (Hanno/Tokyo); Maeshima, S.; Osawa, A. (Hidaka); Nishio, D. (Hanno/Otawara); Takeda, K.; Baba, M.; Kigawa, H. (Hanno)
229 Fractional Anisotropy in Three Variants of Primary Progressive Aphasia

Magnin, E.; Cattin, F.; Vandel, P.; Galmiche, J.; Moulin, T.; Rumbach, L. (Besançon)

240 Influence of Spatial Neglect, Hemianopia and Hemispace on the Subjective Vertical

Saj, A. (Geneva); Honoré, J.; Bernati, T.; Rousseaux, M. (Lille)

Neurology and Art

247 Neurology and Don Quixote

Palma, J.-A. (Pamplona); Palma, F. (Granada)

Neurological Vignette

259 Syrinx Exceptionally Revealed by Isolated Bilateral Horner's Syndrome

Ciron, J.; Blanc, J.-L.; Bouamama, N.; Mathis, S.; Neau, J.-P. (Poitiers)

260 Infectious Intracranial Aneurysm Presenting with a Series of Strokes as a Complication of Pneumococcal Meningitis

Choi, K.-H. (Gwangju/Hwasun); Park, M.-S.; Kim, J.-T. (Gwangju); Nam, T.-S.; Choi, S.-M. (Hwasun); Lee, S.-H.; Kim, B.-C.; Kim, M.-K.; Cho, K.-H. (Gwangju)

Correspondence

258 Acute Simultaneous Multiple Lacunar Infarcts: A Severe Disease Entity in Small Artery Disease

Chang, G.Y. (Phoenix, Ariz.) 